Jurnal Kejuruteraan SI1(3) 2018: 31-36

http://dx.doi.org/10.17576/jkukm-2018-si1(3)-05

\title{
Concepts and Challenges of Nanofluids and Phase Change Material (PCM) in Photovoltaic Thermal (PV/T) Collectors: A Review
}

\author{
(Konsep dan Cabaran Bendalir Nano dan Bahan Ubah Fasa (PCM) dalam Pengumpul Fotovolta Terma (PV/T): \\ Satu Ulasan)
}

Ali H. A. Alwaeli*, Kamaruzzaman Sopian, Adnan Ibrahim, Sohif Mat, Mohd Hafidz Ruslan Solar Energy Research Institute (SERI), Universiti Kebangsaan Malaysia, Malaysia

\begin{abstract}
Recent innovations in high efficiency photovoltaic thermal (PV/T) collectors have made them most suitable renewable energy systems to be integrated in green buildings or utilized in industrial processes. This is attributed to the ability to produce electricity and thermal energy at once. The development in PV/T collectors have reached a new height with the implementation of nanofluids as cooling fluids. Another method that is gaining attraction is the use of Phase Change Material (PCM) to control the temperature of PV panels to maintain its open circuit voltage. This paper aims to review and determine the influence of nanofluids and phase change material on the performance of PV/T collectors in different system configurations (e.g. buildings, both industrial and residential). A comparison between the two, accompanied by an introduction of innovative work in this field is presented as well. The influence of nanofluids and phase change material is immense; from raising the thermal efficiency to raising the operating electrical efficiency and reduce overall payback period of the system. This signifies the importance of performing critical review to establish a clearer understanding of suitable configuration of nanofluid and PCM based PV/T collectors.
\end{abstract}

Keywords: Phase Change Material (PCM); nanofluids; PV/T; pay-back period; efficiency

ABSTRAK

Inovasi terkini dalam pengumpul fotovolta terma (PV/T) berkecekapan tinggi menghasilkan sistem tenaga keterbaharuan yang paling sesuai untuk disepadukan dalam bangunan hijau atau digunakan dalam proses perindustrian. Ini disebabkan oleh kemampuan untuk menghasilkan tenaga elektrik dan haba sekaligus. Pembangunan dalam PV/T telah mencapai tahap yang tinggi dengan penggunaan bendalir nano sebagai cecair penyejuk. Kaedah lain yang menarik adalah penggunaan bahan berubah fasa (PCM) untuk mengawal suhu panel PV untuk mengekalkan voltan litar terbukanya. Makalah ini bertujuan untuk menilai pengaruh bendalir nano dan bahan berubah fasa pada prestasi pengumpul PV/T di pelbagai konfigurasi berbeza seperti bangunan, kedua-dua industri dan kediaman. Perbandingan antara kedua-dua bahan ini, disertai dengan pengenalan kerja inovatif dalam bidang ini juga dipaparkan. Pengaruh bendalir nano dan bahan berubah fasa adalah sangat besar; daripada menaikkan kecekapan terma untuk meningkatkan kecekapan elektrik yang beroperasi, dan mengurangkan tempoh bayaran balik keseluruhan sistem. Ini menandakan pentingnya mengkaji semula secara kritikal untuk mewujudkan pemahaman yang lebih jelas tentang konfigurasi PV/T berasaskan bendalir nano dan PCM yang sesuai.

Kata kunci: Bahan berubah fasa (PCM); bendalir nano; PV/T; tempoh bayaran balik; kecekapan

\section{INTRODUCTION}

Solar energy offers a clean, abundant, and climate-friendly energy resource to mankind, relatively well-spread over the Earth (Sakib \& Ahad 2018). The main aims of solar energy industry are to raise the efficiency and reduce the costs of solar collectors. This includes both photovoltaic (PV) panels and solar thermal collectors. PV panels are semi-conductor devices that converts sunlight into electricity, as direct current (DC) (Chaichan et al. 2018; Green 1982; Wahab 2011). While the solar thermal collector absorbs the heat of the solar radiation, which is then conveyed by a working fluid (e.g. water). Temperature is useful for the solar thermal collectors but is damaging for the PV cell. This is because increase in PV cell temperature leads to decrease in its open circuit voltage
(VOC). Where for every $10^{\circ} \mathrm{C}$ of temperature increase causes a decrease of 5\% in PV panel efficiency (Chow et al. 2003). Hence, the efficiency will drop, and the lifetime of the device will be lower. This problem could be solved using different cooling methods, with the criteria being to maintain the costs while raising the efficiency. One method is to utilize phase change material (PCM) such as paraffin-wax to control the temperature of the PV panel and so protect it from the heat over the operation period (Stritih 2016). The disadvantage in this method is that PCM wax has relatively low thermal conductivity. Another method is to combine the PV module and the solar thermal collector, creating a photovoltaic thermal (PV/T) collector. This collector will produce both electrical and thermal energy. The thermal absorber will be attached to the back of the PV panel; drawing the temperature through 
conduction. This temperature is then transmitted using the working fluid. This provides cooling for the PV panel while simultaneously producing thermal energy (Charalambous et al. 2007). Therefore, it is important to raise the thermal conductivity of the fluid. Hence, innovative research was conducted to implement nanofluids as the working fluids in PV/T collectors, as they exhibit better thermophysical properties (Choi \& Eastman 1995).

The main challenges in this solution will be the relative high costs, preparation time $\&$ method, appropriate thermophysical properties, proper nanomaterial selection and the issue of precipitation and agglomeration. Phase change material and nanofluids are complex and attractive topics of discussion and has been implemented to enhance solar energy system. The aim of this paper is to explore the influence of nanofluids and PCM on PV/T collectors for residential and commercial buildings and assess their importance for further research in solar energy.

\section{NANOFLUIDS}

A nanofluid is a fluid that contains nanometer-sized particles, called nanoparticles. During recent decades, investigation into the synthesis and characterization of nanoparticles continues to remain an active area of research (Ibrahim et al. 2015). The nanofluids are engineered colloidal suspensions of nanoparticles in a base fluid. The nanoparticles used are made of metals, carbides, or carbon nanotubes (Buongiorno 2006). Whereas the base fluids commonly include water, ethylene glycol and oil. Nanofluids are implemented in solar heat exchangers to improve their heat transfer properties. This method is considered recent. This application is attributed to their thermophysical properties; thermal conductivity, viscosity and density, which are superior to water for this application (Yu et al. 2008).

The process of selection and preparation of nanofluids is crucial, as it carries significant effects on the cost and energy production of the PV/T. Hence, thermophysical property tests are conducted, along with different scanning methods, when testing and characterizing nanoparticles. Figure 1 shows a field emission scanning electron microscope (FESEM) image of SiC nanomaterial. A major factor to test is the volume fraction (wt.\% ) of nanomaterial in the base fluids (Xuan \& $\mathrm{Li}, 2003$ ). Generally, researchers produce different samples to test the effect of increasing the volume fraction on the thermal conductivity. Radwan et al. (2016) used a SiC nanofluid with a volume fraction $4 \% v / v$ in a microchannel heat sink to cool the PV/T system. Moreover, different nanomaterial is also tested, to find the best one for such applications. Minea (2017) investigated three oxide-based nanofluids, by testing their thermophysical properties. While, Manikan \& Rajan (2016) investigated thermophysical properties of surfactantfree, sand-propylene glycol-water nanofluids for solar energy collection. However, both authors noticed an increase in thermal conductivity; which is attributed to addition of nanomaterial to the base fluid.

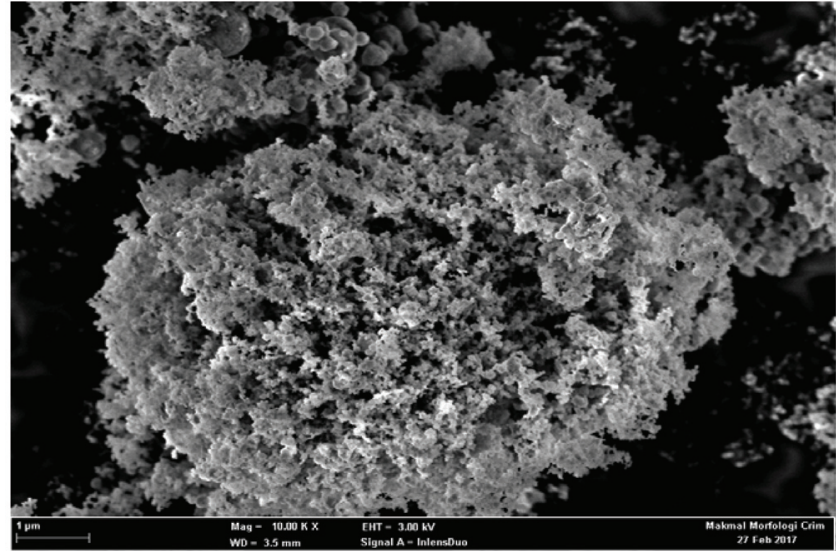

FIGURE 1. FESEM of SiC nanoparticles (Al-Waeli et al. 2017)

There are two mixing processes to produce these nanofluids; which are the one step and the two step methods. The two-step method is simply conducted by adding nanopowder into base fluid in an ultrasonic shaker for it to sonicate and homogenize. Usually, surfactant is added to improve the mixing process. Once nanofluid is produced, it is tested in the system to examine its influence on PV/T collector. The criteria of evaluation are the electrical and thermal energies of the system. Crisostomo et al. (2017) used Ag- $\mathrm{SiO}_{2} /$ water nanofluid with a filter for a concentrating PV/T system. The study proposed the optical and heat transfer model of this system and validated this model through outdoor experiments. The findings show a $12 \%$ increase in weighted energy yield compared to the conventional PV system.

Other researchers conduct indoor experiments in this topic by performing experiment under Standard Testing Conditions (STC). Ghadiri et al. (2015) used $\mathrm{Fe}_{2} \mathrm{O}_{4}$-water nanofluid for a PV/T system to investigate its affects. The study was conducted indoor using solar simulator. Davarnejad et al. (2013) used nano- $\mathrm{Al}_{2} \mathrm{O}_{3}$ to investigate the heat transfer characteristics in a circular tube under constant heat flux, using a CFD simulation software. The results in the literature provide an impression to how useful nanofluids are to the cooling of PV/T systems. CFD is useful to simulate the entity used for the experiments, which is done by Khanjari et al. (2016) as well to study two types of nanofluids; Ag-water and $\mathrm{Al}_{2} \mathrm{O}_{3}$-water nanofluids, as coolants of $\mathrm{PV} / \mathrm{T}$ system. The study concludes that higher percentage in increase in heat transfer coefficient are achieved by Ag-water with 43\%, while alumina-water leads to $12 \%$ increase. There are a number of issues that needs to be tackled like the stability of these fluids, their thermophysical properties over extended periods of time and the effect of continuous heating-cooling cycles. Other issues such as optimum preparation and mixing method, along with end-user product of the nanofluid. Figure 2 shows the method followed in producing nanofluids. 


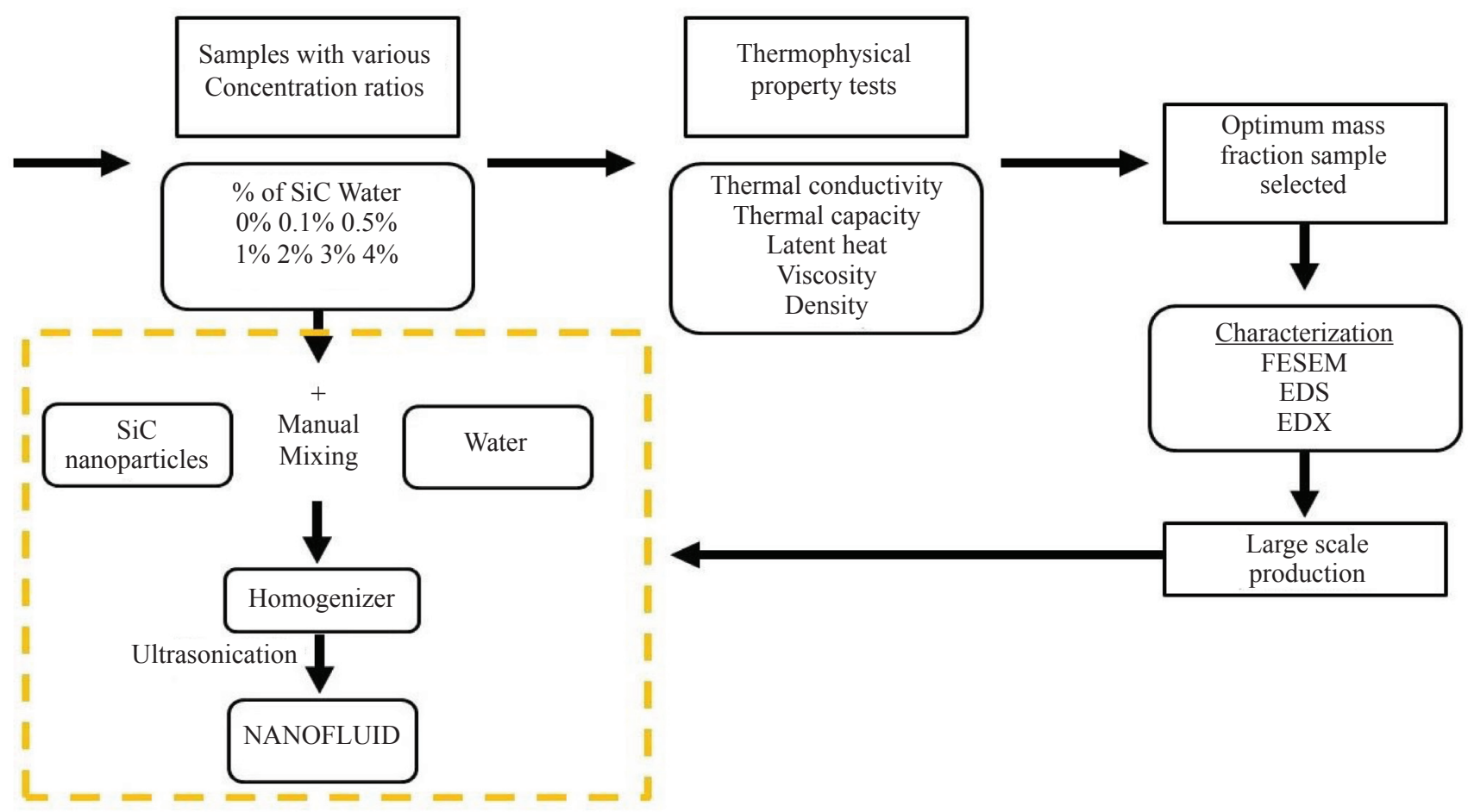

FIGURE 2. The preparation process of nanofluids (using two step method)

PHASE CHANGE MATERIAL (PCM)

Materials that absorb and release heat at constant temperature using the solid-liquid Phase change process, are known as Phase Change Materials (PCMs) (Mancin et al. 2015; Qiu et al. 2015). They can store and release high amounts of thermal energy with insignificant variation in temperature, which makes PCMs widely used in thermal storage (Zalba et al. 2003). PCM can be classified into organic and non-organic or based on their melting temperatures. Organic paraffin is a commonly preferred type of PCM because it is readily available in the market, relatively cheap and is available in different melting points, selected to suit the application. In addition, it is non-corrosive, thermally and chemically stable. PCM are integrated with PV panels because they make it harder for the surface temperature to reach the points of which it becomes problematic (Agyenim et al. 2010).

PCMs are stored in a tank, typically, and attached to the back of PV panel and is heated till it reaches the melting/ solidification temperature. The latent heat absorbed by the PCM causes it to melt. The PCM should be implemented in PV/T or PV systems that has high temperature during daytime and low temperatures during nighttime, to ensure melting with high heat extraction rate, and solidification for regeneration to be ready for use the next day. Desirable characteristics of a solid-liquid PCM include high heat of fusion per volume, congruent melting and freezing characteristics, high thermal conductivity, minimal supercooling, and low thermal expansion. Biwole et al. (2013) experimentally investigated in two different climates, where electrical and thermal efficiency are evaluated to check whether these systems are cost-effective and/or useful in maintaining PV lifetime.
The authors conclude that the system is financially useful for high temperature and high solar radiation environments (e.g. United Arab Emirates). Hasan et al. (2014) confirmed the same conclusion, that weather affected the performance of the PCM attached with the PV.

Figure 3 shows a drawing-design of a typical PV and $\mathrm{PV} / \mathrm{T}$ systems with PCM. The main issue associated with PCM is its relatively low thermal conductivity. The solution to this problem, as presented in the literature, is by encapsulating $\mathrm{PCM}$ to raise its thermal conductivity. One method is to employ nanoparticles in PCM, which is known as nano-PCMs. This addition causes thermal conductivity and capacity enhancement in PCM and allows it to recover better which ensures higher stability of the material under continuous heat-cooling cycles.

Huang et al. (2011) obtained nano-PCMs to enhance thermal properties of pure paraffin, and hence storage capabilities, by implementing alumina and carbon black (CB) nanoparticles in it. The study examines RT20 and RT25 paraffin, to study the effects of the employed nanoparticles. The study claims that highest latent heat was found when $\mathrm{Al}_{2} \mathrm{O}_{3}$ is employed in RT25. While, the lowest is found in the RT25/CB combination. Hence, the study concluded that $\mathrm{Al}_{2} \mathrm{O}_{3}$ enhanced the properties of the paraffin while $\mathrm{CB}$ degraded it.

The cost enhancement caused by employing nanoparticles into PCM needs to be considered in all research as its considered one of the major drawbacks for this design. Another issue is the number of cycles PCM can withstand which is a topic that remains unexplored. Finally, the complication attributed to utilizing the two-step method; which is also a problem for the end-user. Another area of interest is the charging and 
discharging process and how it will affect the panel after sunset as some temperature will remain stored (Chaichan et al. 2016; Chaichan and Kazem, 2015; Colla et al. 2017; Nada et al. 2018). A summary of research works from the recent literature is provided in Table 1.

The table shows a broad range of study methods, investigated material, and system configurations in this field, which include the use of artificial neural networks for performance prediction of these collectors by importing experimental data sets for training the neural network and running the simulation, CFD for assessment of collector thermal behavior, COMSOL Multiphysics for 3D simulation of surface temperature and streamline plot. The common element in all experimental setups is solar irradiance, ambient and surface temperature measurements along with comparison between proposed systems and conventional PV collectors. Which is another essential aspect to research in the field, as it operates as a reference for the behavior of PV in the same study location.

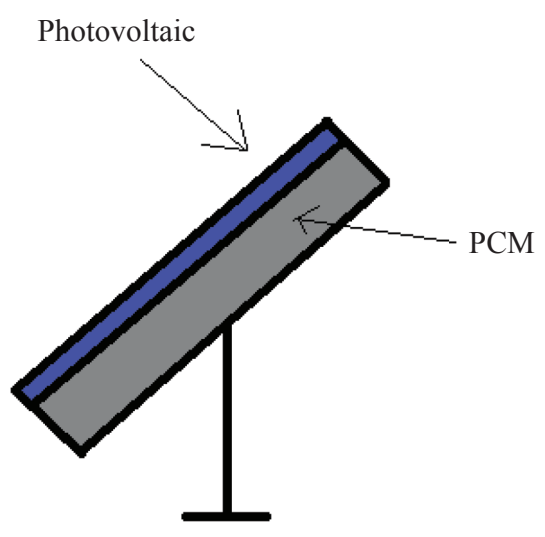

(a) PV-PCM

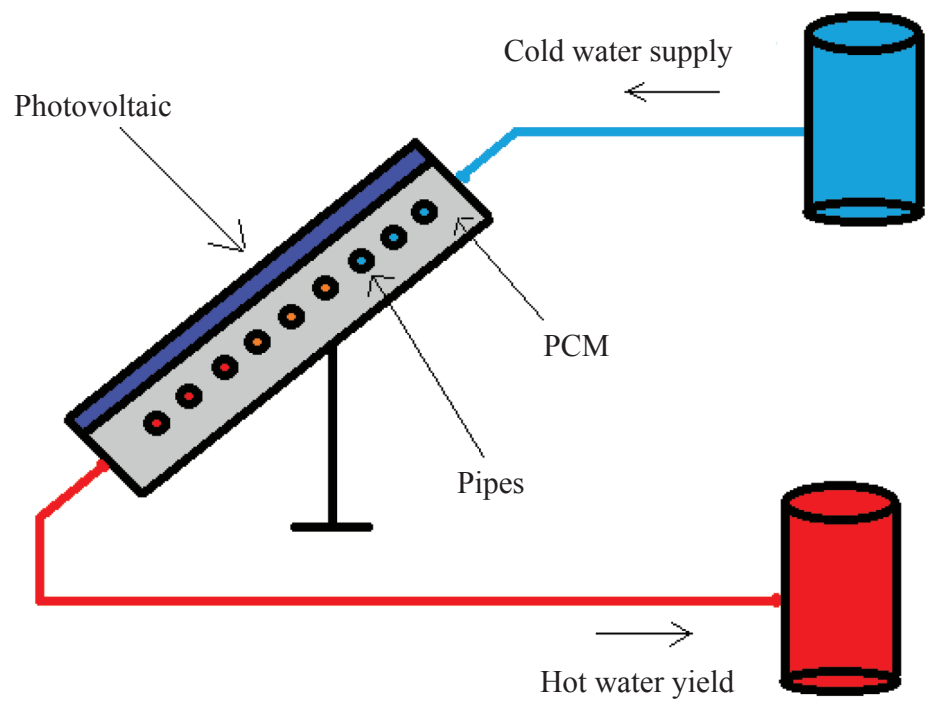

(b) PV/T-PCM

FIGURE 3. PV and PV/T-PCM cross

TABLE 1. Summary of recent literature on PCM and nanofluid based PV/T

\begin{tabular}{|c|c|c|c|}
\hline References & System & Material & Method \\
\hline Al-Waeli et al. 2018 & $\begin{array}{l}\text { Flat Plat } \mathrm{PV} / \mathrm{T} \text { with nanomaterial } \\
\text { and nano-PCM }\end{array}$ & $\mathrm{SiC}$ nanofluids and SiC- Paraffin Wax & $\begin{array}{l}\text { Experimental (outdoors) } \\
\text { and Simulation (ANN) }\end{array}$ \\
\hline Hosseinzadeh et al. 2018 & $\mathrm{PV} / \mathrm{T}$ with nanofluid and PCM & $\mathrm{ZnO} /$ water nanofluid and Paraffin Wax & Experimental (outdoors) \\
\hline Nasrin et al. 2018 & $\mathrm{PV} / \mathrm{T}$ with nanofluid & Water/MWCNT nanofluid & $\begin{array}{l}\text { Experimental (indoors) } \\
\text { and numerical ( } 3 \mathrm{D} \text { numerical } \\
\text { simulation) }\end{array}$ \\
\hline Abdulateef et al. 2018 & $\begin{array}{l}\text { LHTES system using nano- } \\
\text { PCM with fins }\end{array}$ & $\mathrm{Al}_{2} \mathrm{O}_{3}$ nanoparticle with Paraffin Wax & $\begin{array}{l}\text { Experimental (outdoors) and } \\
\text { numerical (CFD) }\end{array}$ \\
\hline
\end{tabular}

Building integrated PV and PV/T systems are crucial to achieving grid and energy independency in the 21 st century. This topic has increasing popularity as zero net energy and autonomous systems are a major attraction in the solar energy market. Hence, they are a major attraction for research and development. BIPV and BIPV/T systems can be implemented in residential, commercial and industrial process. For each application, a design criterion must be tailored to ensure optimum utilization of these technologies (Thaib et al. 2018). For example, high noise in industrial applications is somewhat acceptable but is not in commercial and residential applications.
The integration of the PV system is low-sized PV panels, medium-sized and large-sized for residential, commercial and industrial buildings, respectively. The sizing of the PV system is crucial and affects other system components greatly. For instance, the wires should be selected based on the output current of the panel to avoid high voltage drops and wire burning. The usage of standalone or grid-connected configuration is another criterion that requires careful planning. Standalone systems require batteries for storage and batteries must be situated safely under proper conditions to maintain their lifetime. Also, whether a standalone system 
can support the load demand or a good portion of it. All these factors must be taken into consideration.

The implementation of nanofluids and PCMs may be good for the system performance. This can be tested by manufacturing an experimental setup. The system can be made indoor but with roof considerations only. If so, the setup must contain solar simulator or a source of artificial sun, standard testing conditions (STC) and suitable temperature measurements of the cell, nanofluids, PCM. Moreover, measurement of nanofluids' flowrate is very important. Finally, recording of voltage and current is essential to find the effect of the cooling on the panels. However, these materials will introduce a new set of complications that needs to be answered, which are mentioned in sections I and II. Several important questions must be tackled to solve the prominent issues in this field, which are listed below:

1. What is the optimum mass fraction of nanomaterial in base fluid and PCM, to produce a nanofluid/nano-PCM that balances between thermal conductivity enhancement and corresponding cost?

2. How to avoid agglomeration and sedimentation of nanoparticles during the mixing process, to produce ideal nanofluids?

3. What is the performance of a nanofluid based PV/T collectors after operating for long periods?

4. How to deliver nanofluids and nano-PCMs to the endconsumer for residential PV/T systems?

5. How many heating-cooling cycles can PCM and nanoPCMs last without degradation?

6. What is the optimum material for the PCM/nano-PCM storage tank?

7. What is the optimum viscosity of the nanofluid in the PV/T system?

The optimum design must fulfill the criteria of cost, efficiency and lifetime. Easy installation and maintenance is important to attract the end-user, particularly in residential applications. The solution with highest potential is the solution that combines efficient cooling of PV panel and maximization of thermal output. Combining nano-PCM and nanofluids is an interesting way to fulfilling these criteria. However, finding the right mechanism of maintenance remains somewhat of an issue.

\section{CONCLUSION}

In conclusion, this paper presents the concept of implementing nanofluids and phase change material in photovoltaic thermal $(\mathrm{PV} / \mathrm{T})$ systems. The two types of material are introduced and their effect on PV and PV/T collectors are explained. Nanomaterial has gained massive popularity by researchers in the field due to its superior thermophysical properties. PCM and nano-PCM has also been an area of attraction. Although, more work on analyzing the charging and discharging periods of the PCM, it is a topic that is fairly addressed. All in all, nanofluids and PCM are cost-effective and useful for solar energy technology and building integrated systems.

\section{ACKNOWLEDGEMENT}

The authors would like to thank the Universiti Kebangsaan Malaysia (UKM) for funding using the grant (DPP-2018002).

\section{REFERENCES}

Abdulateef, A.M., Mat, S., Abdulateef, J., Sopian, K. \& AlAbidi, A. A. 2018. Thermal performance enhancement of triplex tube latent thermal storage using fins-nano-phase change material technique. Heat Transfer Engineering 39(12): 1067-1080.

Agyenim, F., Hewitt, N., Eames, P. \& Smyth, M. 2010. A review of materials, heat transfer and phase change problem formulation for latent heat thermal energy storage systems (LHTESS). Renewable and Sustainable Energy Reviews 14(2): 615-628.

Al-Waeli, A. H., Sopian, K., Chaichan, M. T., Kazem, H. A., Hasan, H. A. \& Al-Shamani, A. N. 2017. An experimental investigation of sic nanofluid as a basefluid for a photovoltaic thermal PV/T system. Energy Conversion and Management 142: 547-558.

Al-Waeli, A. H., Sopian, K., Kazem, H. A., Yousif, J. H., Chaichan, M. T., Ibrahim, A., Mat, S. \& Ruslan, M. H. 2018. Comparison of prediction methods of PV/T nanofluid and nano-pcm system using a measured dataset and artificial neural network. Solar Energy 162: 378-396.

Biwole, P. H., Eclache, P. \& Kuznik, F. 2013. Phase-change materials to improve solar panel's performance. Energy and Buildings 62: 59-67.

Buongiorno, J. 2006. Convective transport in nanofluids. Journal of Heat Transfer 128(3): 240-250.

Chaichan, M. T., Abaas, K. I. \& Kazem, H. A. 2016. Design and assessment of solar concentrator distillating system using phase change materials (PCM) suitable for desertic weathers. Desalination and Water Treatment 57(32): 14897-14907.

Chaichan, M. T. \& Kazem, H. A. 2015. Water solar distiller productivity enhancement using concentrating solar water heater and phase change material (PCM). Case Studies in Thermal Engineering 5: 151-159.

Chaichan, M. T. \& Kazem, H. A. 2018. Generating electricity using photovoltaic solar plants in Iraq. Springer, 4782.

Charalambous, P., Maidment, G. G., Kalogirou, S. A. \& Yiakoumetti, K. 2007. Photovoltaic thermal (PV/T) collectors: A review. Applied Thermal Engineering 27(2-3): 275-286.

Choi, S. U. \& Eastman, J. A. 1995. Enhancing thermal conductivity of fluids with nanoparticles. $A S M E$ Publications-Fed 231: 99-106.

Chow, T., Hand, J. \& Strachan, P. 2003. Building-integrated photovoltaic and thermal applications in a subtropical hotel building. Applied Thermal Engineering 23(16): 2035-2049. 
Colla, L., Fedele, L., Mancin, S., Danza, L. \& Manca, O. 2017. Nano-PCMs for enhanced energy storage and passive cooling applications. Applied Thermal Engineering. 110: 584-589.

Crisostomo, F., Hjerrild, N., Mesgari, S., Li, Q. \& Taylor, R. A. 2017. A hybrid PV/T collector using spectrally selective absorbing nanofluids. Applied Energy 193: $1-14$.

Davarnejad, R., Barati, S. \& Kooshki, M. 2013. CFD simulation of the effect of particle size on the nanofluids convective heat transfer in the developed region in a circular tube. SpringerPlus 2(1): 192.

Ghadiri, M., Sardarabadi, M., Pasandideh-Fard, M. \& Moghadam, A. J. 2015. Experimental investigation of a PVT system performance using nano ferrofluids. Energy Conversion and Management, 103: 468-476.

Green, M. A. 1982. Solar Cells: Operating Principles, Technology, and System Applications. Englewood Cliffs, NJ, Prentice-Hall, Inc., 288.

Hasan, A., Mccormack, S. J., Huang, M. J. \& Norton, B. 2014. Energy and cost saving of a photovoltaicphase change materials (PV-PCM) system through temperature regulation and performance enhancement of photovoltaics. Energies 7(3): 1318-1331.

Hosseinzadeh, M., Sardarabadi, M. \& Passandideh-Fard, M. 2018. Energy and exergy analysis of nanofluid based photovoltaic thermal system integrated with phase change material. Energy 147: 636-647.

Huang, M., Eames, P., Norton, B. \& Hewitt, N. 2011. Natural convection in an internally finned phase change material heat sink for the thermal management of photovoltaics. Solar Energy Materials and Solar Cells 95(7): 15981603.

Ibrahim, R.M., Markom, M. \& Razak, K.F.A. 2015. Optical properties of $\mathrm{Fe}^{2+}$ ion doped $\mathrm{ZnS}$ nanoparticles synthesized using co-precipitation method. Jurnal Kejuruteraan 27: 87-94.

Khanjari, Y., Pourfayaz, F. \& Kasaeian, A. 2016. Numerical investigation on using of nanofluid in a water-cooled photovoltaic thermal system. Energy Conversion and Management 122: 263-278.

Mancin, S., Diani, A., Doretti, L., Hooman, K. \& Rossetto, L. 2015. Experimental analysis of phase change phenomenon of paraffin waxes embedded in copper foams. International Journal of Thermal Sciences 90: 79-89.

Manikandan, S. \& Rajan, K. 2016. Sand-propylene glycolwater nanofluids for improved solar energy collection. Energy 113: 917-929.

Minea, A. A. 2017. Hybrid nanofluids based on $\mathrm{Al}_{2} \mathrm{O}_{3}, \mathrm{TiO}_{2}$ and $\mathrm{SiO}_{2}$ : Numerical evaluation of different approaches. International Journal of Heat and Mass Transfer 104: $852-860$

Nada, S., El-Nagar, D. \& Hussein, H. 2018. Improving the thermal regulation and efficiency enhancement of PCMIntegrated PV modules using nano particles. Energy Conversion and Management 166: 735-743.
Nasrin, R., Rahim, N., Fayaz, H. \& Hasanuzzaman, M. 2018. Water/MWCNT Nanofluid based cooling system of PVT: Experimental and numerical research. Renewable Energy 121: 286-300.

Qiu, Z., Zhao, X., Li, P., Zhang, X., Ali, S. \& Tan, J. 2015. Theoretical investigation of the energy performance of a novel MPCM (Microencapsulated Phase Change Material) slurry based PV/T module. Energy 87: 686698.

Radwan, A., Ahmed, M. \& Ookawara, S. 2016. Performance enhancement of concentrated photovoltaic systems using a microchannel heat sink with nanofluids. Energy Conversion and Management 119: 289-303.

Sakib, N. \& Ahad, M.A.R. 2018. An optimized structure for enhancing optical absorption of solar energy in elliptical gaas nanowire array solar cell. Jurnal Kejuruteraan 30(1): $1-6$.

Stritih, U. 2016. Increasing the efficiency of pv panel with the use of PCM. Renewable Energy 97: 671-679.

Thaib, R., Rizal, S., Mahlia, T. \& Pambudi, N. A. 2018. Experimental Analysis of Using Beeswax as Phase Change Materials for Limiting Temperature Rise in Building Integrated Photovoltaics. Case Studies in Thermal Engineering 12: 223-227.

Wahab, A. K. A. 2011. Application of solar energy in Malaysia. Thesis Masters Universiti Malaya.

Xuan, Y. \& Li, Q. 2003. Investigation on convective heat transfer and flow features of nanofluids. Journal of Heat Transfer 125(1): 151-155.

Yu, W., France, D. M., Routbort, J. L. \& Choi, S. U. 2008. Review and comparison of nanofluid thermal conductivity and heat transfer enhancements. Heat Transfer Engineering 29(5): 432-460.

Zalba, B., Marın, J. M., Cabeza, L. F. \& Mehling, H. 2003. Review on thermal energy storage with phase change: Materials, heat transfer analysis and applications. Applied Thermal Engineering 23(3): 251-283.

*Ali H. A. Alwaeli, Kamaruzzaman Sopian, Adnan Ibrahim, Sohif Mat, Mohd Hafidz Ruslan

Solar Energy Research Institute (SERI),

Universiti Kebangsaan Malaysia,

43600 Bangi, Malaysia.

*Corresponding author; email: ali9alwaeli@gmail.com

Received date: $28^{\text {th }}$ May 2018

Accepted date: $21^{\text {st }}$ July 2018

Online first date: $1^{\text {st }}$ October 2018

Published date: $30^{\text {th }}$ November 2018 